\title{
Kaasava hariduse mõiste ning õpetaja ees seisvad ülesanded lasteaedades ja esimeses kooliastmes
}

\author{
Pille Häidkind $^{\mathrm{a}}$, Kaja Oras ${ }^{\mathrm{b}}$ \\ ${ }^{a}$ Tartu Ülikooli haridusteaduste instituut \\ ${ }^{b}$ Tallinna Ülikooli rahvusvaheliste sotsiaaluuringute keskus
}

\begin{abstract}
Annotatsioon
Kaasava hariduse eesmärk on suurendada haridussüsteemi võimekust jõuda kõikide õppijateni, põhiliseks sihtgrupiks on enamikus riikides hariduslike erivajadustega õppijad. Siinse uurimuse eesmärk on selgitada välja, kuidas mõistetakse kaasavat haridust Eesti lasteaedades ja koolides (esimene kooliaste) ning millised on õpetajate ees seisvad ülesanded ja asutuste võimalused erivajadustega õppijate kaasamisel tavaharidussüsteemi. Andmeid kogusime küsitluse ja vaatluse teel, lisaks analüüsisime kaasamise edendamise kavasid. Saadud tulemused võimaldavad käsitleda erivajadustega õppija teemat sügavuti ja tõhustada õpetajakoolitust. Hädavajalik on valmistada õpetajaid ette erivajadustega õppija ja ülejäänud laste koosõpetamiseks (grupiprotsessid, -juhtimine), laiendada arusaamu keskkonna kohandamise võimalustest ning suurendada valmisolekut meeskonnatööks.
\end{abstract}

Võtmesõnad: kaasav haridus, hariduslike erivajadustega lapsed, lasteaiaõpetajad, klassiõpetajad

\section{Sissejuhatus}

Kaasavat haridust uurima asudes tekib esimesena küsimus, mida me õieti uurime. UNESCO poliitiliste suuniste dokumendis (2009, viidatud Euroopa Eripedagoogika Arendamise Agentuur, 2009 järgi) tuuakse välja, et kaasava hariduse eesmärk on tugevdada haridussüsteemi võimekust jõuda kõikide õppijateni. Tõdetakse, et kaasamine ja hariduse kvaliteet on vastastikuse mõjuga - iga õppijaga arvestamine on see, kuhu hariduses püüeldakse. Järelikult tuleb kaasava hariduse sihtrühmaks pidada kõiki piirkonna (Eestis 
kohaliku omavalitsuse) õppijaid. Lastekaitse Liidu (2014) 7-26aastaste õppijate seas tehtud uuringu kokkuvõttes on kirjas: „Arenenud demokraatiat iseloomustab ühiskonna kõigi sotsiaalsete rühmade (sh laste ja noorte) huvide ja vajadustega arvestamine ning nende sotsiaalne kaasatus" (lk 4). Ka Robo (2014) rõhutab sotsiaalset kaasamist ja leiab, et selleni saab jõuda eelkõige haridusliku kaasamise kaudu. Käsitledes kaasamist kui isikute osalemist neid puudutavates otsustes, protsessides, on teemakohased ka sellised väljendid nagu lapsevanemate kaasamine ja tugispetsialistide kaasamine (õppijate toetamiseks).

Hariduse ja kasvatuse sõnaraamatus (HKS, 2014) on kaasav haridus võrdsustatud haridusliku kaasamisega ning viimast defineeritud kui „hariduskäsitust, mille kohaselt õpetatakse erivajadusega lapsi koos eakohaselt arenenud lastega kodulähedases koolis" (lk 185). Eesti Haridus- ja Teadusministeeriumi (2016) kodulehel määratletakse kaasava hariduse olemust järgmiselt: „Hariduslike erivajadustega õpilaste õppekorralduses lähtutakse kaasava hariduse põhimõttest, mille kohaselt õpivad hariduslike erivajadustega õpilased üldjuhul elukohajärgses tavakoolis." Seega tegeletakse Eestis kaasava hariduse raames eelkõige sellega, kuidas kaasata erivajadustega õppijaid tavalistesse lasteaedadesse ja koolidesse (kaasav haridus pigem kitsas tähenduses).

Kaasava hariduse defineerimise problemaatilisusele on osutatud ka väliskirjanduses (Loreman, Forlin, Chambers, Sharma, \& Deppeler, 2014; Vujačić \& Đević, 2013). Nes (2003) põhjendab olukorda sellega, et erivajadustega õppijaid ei tohi kõrvale tõrjuda, sest kool on mõeldud kõikidele. Autor toob kõikide õppijatega arvestamise kohta näiteid Aafrikast, kus kooli ei pruugi jõuda tööl käivad või riieteta lapsed, ning Skandinaaviast, kus erivajadustega lapsed võivad suure osa koolipäevast olla teistest eraldi. Seega sõltub nähtavasti konkreetsest riigist, millise osaga õppijatest tuleb kaasava hariduse edendamisel rohkem tegeleda.

Kõrgesaare (2002) hinnangul võib erivajadustega õpilasi üldgrupis olla ligikaudu 25\%, hulk oleneb paljuski definitsioonist. Haridussüsteemis on erivajaduste defineerimise aluseks see, mil määral õppija eristub samas grupis õppijatest ning vajab keskkonna kohandamist. Haridus- ja Teadusministeeriumi (2015) andmetel käis 2012/2013. õppeaastal koolieelsetes lasteasutustes 8503 erivajadustega last (12,7\% lasteasutuses käivatest lastest). Eesti Hariduse Infosüsteemi (2012, viidatud Haridus- ja Teadusministeerium, 2013 järgi) andmetel esines 16,8\% üldhariduskooli õpilastest erineva tunnusega hariduslik erivajadus. $76 \%$ neist õpilastest käis üldhariduskooli tavaklassis, sagedamini olid nad püsiva või ajutise õpiraskusega või psüühika- ja käitumishäiretega, harvem puuetega. 9\% erivajadustega õpilastest 
óppis tavakoolide eriklassides (ibid.). Nn tavaliste ja erivajadustega laste vahepeale jäävad aga need lapsed, kes grupist eristuvad, kuid kelle erinevus ei ole kas piisavalt suur või seda ei märgata.

Erivajadustega arvestamine peaks tänapäeval olema loomulik osa haridusasutuste igapäevasest tööst. Olemas on valdkonda reguleerivad õigusaktid nii lasteaia (Koolieelse lasteasutuse riiklik õppekava, 2008; Koolieelse lasteasutuse seadus, 1999) kui ka kooli tarbeks (Põhikooli- ja gümnaasiumiseadus, 2010; Põhikooli riiklik õppekava, 2011), vastu on võetud õpetaja kutsestandardid, loodud maakondlikud Rajaleidja keskused. Kõik need meetmed toetuvad mujal maailmas kokku lepitud kaasava hariduse põhimõtetele, mida on kajastatud erinevates resolutsioonides, deklaratsioonides ja raamistikes 1990. aastast alates (vt Euroopa Eripedagoogika Arendamise Agentuur, 2009).

Arvestades aastakümneid Eestis levinud praktikat, et erivajadustega õppijad olid pigem eakaaslastest eraldi asutustes, rühmades ja klassides, võib öelda, et kaasava hariduse propageerimine ja levik on väga suur muudatus siinsel haridusmaastikul taasiseseisvumisest alates. Vaadeldes seda muudatust kui protsessi, saab kirjeldada kolme etappi: 1) väga selgelt toimivad eraldi süsteemid tava- ja eriõppe jaoks; 2) mitmesuguste tugimeetmete rakendamine tavalises õpikeskkonnas ja 3) kõikide õppijate täielik kaasamine tavaharidussüsteemi (Euroopa Eripedagoogika Arendamise Agentuur, 2009). Hariduslike erivajadustega õpilaste õppekorralduse kontseptsiooni (Haridus- ja Teadusministeerium, 2013) alusel paistab, et Eesti riik on panustanud enam ajutiste ja kergemate erivajadustega õppijate (nn HEV 1) suuremasse kaasamisse tavakoolides ja vähem eriõppeasutuste sälitamisse. Seega on kaasava hariduse teema jätkuvalt aktuaalne ja puudutab väga suurt osa ühiskonnast (lapsed, lapsevanemad, õpetajad, juhid, tugispetsialistid), ühendades üld- ja eripedagoogika valdkondi.

\section{Õpetaja ettevalmistus ja kogemused}

Kaasavat haridust võib analüüsida ühiskonna või piirkonna, asutuse ja indiviidi tasandil (Loreman et al., 2014). Selles artiklis keskendume õpetaja ees seisvatele ülesannetele kaasava hariduse rakendamisel. Kuna suurenenud on õppijate erinevus rühma ja klassi piires, peab tänapäeva õpetaja olema oma lähenemisviisides ääretult paindlik. Õpetaja kutsestandardites (Kollom et al., 2013; Pedaste et al., 2013) rõhutatakse kõikides kompetentsusvaldkondades indiviidikeskset käsitlusviisi ja koostööd (õppijate, kolleegide, lapsevanemate, tugispetsialistidega). Erivajadustega õppijatega arvestamise kohustust kirjeldatakse kahes kompetentsusvaldkonnas: õpi- ja õpetamis- 
tegevuse kavandamine (B 2.1) ning õppimise ja arengu toetamine (B 2.3). Õpetaja pädevuses on õpikeskkonna kujundamine (B 2.2) sellisena, et see oleks turvaline, toetav ja (kõikide) õppijate vajadusi arvestav. Rühmas ja klassis valitsev õhkkond on oluline tegur, mis mõjutab õppimise tõhusust, õpimotivatsiooni, üldist rahulolu, õpiväljundeid ja mitmeid muid õppimist soodustavaid asjaolusid (Übius, Kall, Loogma, \& Ümarik, 2014). Seega on õpetaja paindlikkust kutsestandardites täpsustatud ja erivajadustega lapsed kuuluvad õpetaja vastutusalasse. Euroopa Eripedagoogika Arendamise Agentuuri 2011. aasta kogumikus õpetajakoolituse kohta sõnastab sama agentuuri direktor Meijer olukorra väga lihtsalt: „Õpetaja on see, kes kaasava hariduse põhimõtted ellu viib" (lk 5). Kogumiku sõnum on, et kaasamise edendamiseks on kõige olulisem välja töötada sobivad õpetajakoolituse taseme- ja täiendõppe õppekavad ning koolitada õpetajaid järjepidevalt toime tulema õppijatega, kellel on mitmekesised vajadused (vt ka Fullan, 2006; Häidkind, 2013; Kivirand, 2012; Kraska \& Boyle, 2014).

Õpetaja valmisolekut kaasamiseks mõjutab see, mida ta õppimise ja õpetamise kohta teab. 1999. aastal arvas 95,3\% uuritud õpetajatest, et nende ettevalmistus erivajadustega õpilaste õpetamiseks on ebapiisav (Mägi \& Haljaste, 2001), 2008. aastal oli see protsent 28 (Poom-Valickis \& Loogma, 2009) ja 2013. aastal 19 (Kall, 2014). Kruusamäe (2015) on Lääne-Virumaa õpetajaid küsitledes leidnud, et 36,5\% õpetajatest hindab oma ettevalmistust erivajadustega õpilastega tegelemiseks ebapiisavaks. Pedagoogilistest pädevustest peavad õpetajad kõige rohkem arendamist vajavaks oskuseks töötada koos erivajadustega lastega. Nii on hariduslike erivajadustega laste, sh andekate laste arengu toetamine üks prioriteetsetest teemadest õpetajate täiendkoolituses (Balti Uuringute Instituut, 2015).

Teiste riikide kogemus näitab, et kaasava hariduse tingimustes on õpetajale vaja ettevalmistust järgmistel teemadel: demokraatlikud väärtused, põhiterminoloogia, õppija arengu hindamine ja eripärade sõnastamine, õpikeskkonna ja õppekava kohandamine, õpetamine, meeskonnatöö ja koostöö lapsevanematega (kokkuvõtted ja näited riikide kaupa on leitavad kogumikus „Kaasamist toetav õpetajakoolitus Euroopas“) (Euroopa Eripedagoogika Arendamise Agentuur, 2011). Hattie (2012) toob efektiivseid õppimisvõtteid reastades välja, et kõige paremini aitab õppimisele kaasa individuaalne lähenemine. Üksnes lapse teadmistesse, oskustesse süvenedes suudab õpetaja suurendada lapse ootusi tema enda suhtes, kavandada õpetamist lapsele jõukohasena (laps peab pingutama, teeb vigu, vajab vähest abi). Efektiivne on Hattie (2012) järgi reageerida õppimisprobleemidele kiiresti (õpiraskustega laste abistamine on tõhus kooli alguses) ning anda lapsele sisukat tagasisidet ( $\mathrm{nn}$ kujundav hindamine). 
Õppijate sotsiaalsete oskuste arendamisega seoses tasub panustada õpetaja usaldusväärsusesse, kasutada rühmatöid ja tegeleda õpilastevaheliste suhetega (Hattie, 2012). Õpilaste tajutud õpetajapoolne õpilasekesksus, hoolivus, toetavus, sund ja rangus on seotud nende õpitulemuste ja motivatsiooniga (Säälik, Mikk, Krips, \& Kalk, 2013). Õppijate sotsiaalsete ja enesekohaste oskuste teadlik ja sihipärane arendamine, mis ennetab ebasobivate käitumismustrite kujunemist ja kinnistumist (Rogers, 2008; Soiber \& Gettinger, 2011; Tropp \& Saat, 2008), ning lastevaheliste positiivsete suhete toetamine (Shapiro, 2000) on kaasava õpetaja töös väga olulisel kohal.

Kutsekompetentsid arenevad ka kogemustele toetudes. Tavasüsteemi kaasatakse järjest enam ja raskemate erivajadustega õppijaid, nendega puutub kokku üha rohkem õpetajaid. Oras (2003) toob ühe meisterõpetajate ja algajate õpetajate erinevusena välja õpetaja suutlikkuse arvestada erivajadustega lastega teiste õppijate hulgas. Kui õpetaja on nii kogenud ópetamises kui ka tegelenud andekate lastega, siis ta analüüsib õppija tegevust ja olukordi oluliselt sügavamalt kui need algajad või ka kogenud õpetajad, kes pole niisuguste lastega kokku puutunud. Järelikult on tegelik kokkupuude erivajadustega lastega kutsekompetentside arenemise seisukohalt äärmiselt oluline (Spratt \& Florian, 2014).

Õpetaja positiivne hoiak kaasava hariduse suhtes on samuti üks eeltingimusi, et ta kasutaks efektiivseid lähenemisviise teistest eristuvate õppijate toetamiseks (Loreman, Forlin, \& Sharma, 2014; Specht et al., 2016). Lasteaiaõpetajate suhtumine erivajadustega õppijate kaasamisse on valdavalt neutraalne (Bendová, Čecháčková, \& Šádková, 2014; Lee, Yeung, Tracey, \& Barker, 2015). 26 uurimuse kokkuvõtteks leidsid De Boera, Pijlb ja Minnaert (2011), et enamik algklasside õpetajaid suhtub erivajadustega õppijate kaasamisse neutraalselt või negatiivselt. Eha (2010) uurimusest selgus, et kaasava hariduse suhtes on soodsamalt meelestatud noorema kooliastme õpetajad. Pedagoogilised veendumused võivad tuleneda kogemustest ja ettevalmistusest, enesetäiendusest, õpetajaks saamise tee iseärasustest või muudest teguritest ning mõjutada õpetamispraktikat ja klassikliimat (Übius et al., 2014).

Et õpetaja saaks õpilasi tegevustesse tähenduslikult kaasata, tuleb teda selle juures toetada. Kaasava hariduse rakendamisel on tavaharidussüsteemi suunas liikunud ka tugispetsialistid (eripedagoogid, logopeedid, psühholoogid, sotsiaalpedagoogid). Kaasamisel tuleb tähelepanu pöörata osalusele ja õppimisele, mitte sellele, kuidas eemaldada õppija klassist ja suunata ta probleemide lahendamiseks spetsialisti juurde (Naukkarinen, 2010; Pijl, 2010, viidatud Euroopa Eripedagoogika Arendamise Agentuur, 2011 järgi). Seega eeldab kaasav haridus muudatusi ka tugisüsteemis: spetsialistid 
peavad toetama, nõustama ja juhendama, aga ei tohi võtta õpetajalt ega lapsevanematelt juhirolli ära (Euroopa Eripedagoogika Arendamise Agentuur, 2009; Skogen \& Holmberg, 2004; Rodriguez, Saldana, \& Moreno, 2012). Pecek, Cuk ja Lesar (2008) on leidnud, et klassiõpetajad aktsepteerivad ainult vähesel määral vastutuse võtmist erivajadustega õpilaste kaasamise eest.

Õpetaja professionaalse arengu toetamiseks, enesekindluse suurendamiseks ning vastutuse jagamiseks tasub rakendada meeskonnatööd $(\mathrm{Li}$, 2004). Et kaasamine edeneks, on mõistlik teha plaane, jagada rolle ning määrata tähtajad (Jones, 2004). Osa muudatusi eeldab koostööd asutuse tasandil, nt õppekava peatükid, meeskonnatöö, ning osa rühma/klassi tasandil, nt keskkonna füüsilised (Dmitrieva \& Nartova-Bochaver, 2014) ja sotsiaalsed tegurid (Schwab, 2015), õppevormid ja meetodid, individuaalne arendus- või õppekava (Häidkind et al., 2013). Õpetajad peavad vajalikuks spetsiifilisemat ettevalmistust, enam abistavat personali ja laste arvu vähendamist grupis (Bendová et al., 2014; Eha, 2010; Kruusamäe, 2015; Lee et al., 2015; Postak, 2015). Muutunud õpikäsituse (sh individuaalse lähenemise) rakendamisel peab üle $60 \%$ koolijuhtidest ja ligi kolmandik õpetajatest probleemiks väheseid ressursse õppekeskkonna ja -vahendite ajakohastamisel (Balti Uuringute Instituut, 2015).

Haridus- ja Teadusministeeriumi 2014. aasta analüüsis (Haridus- ja Teadusministeerium, 2015) tõdetakse, et „teoreetiliselt omaksvõetud ja dokumentides kinnitatud õpikäsitus, õppijate eri tüüpi andekuste väärtustamine ning erivajaduste märkamine ei ole muutunud õppeprotsessi lahutamatuks osaks" (lk 17); „endiselt on probleemiks erivajadustega lastele ja noortele võrdsete haridusvõimaluste tagamine" (lk 50). Rõhutatakse just varajast märkamist ja probleemidega tegelemist lasteaias ja algklassides, et ennetada haridustee katkestamist. Kaasamise ebaõnnestumisel jäävad erivajadustega lapsed vajaliku õpetuseta (Hornby, 2014; Karlep, 2015).

\section{Uurimisprobleem ja eesmärk}

Fullani (2006) järgi toimuvad muudatused haridusmaastikul pigem aeglaselt ning uuenduste elluviimine eeldab piisavat üleminekuaega ja teemaga süvitsi tegelemist. Nüüdseks on möödunud 15-20 aastat kaasava hariduse idee levimisest Eestisse. Viimase aja uurimustes (Kruusamäe, 2015; Postak, 2015) on osutatud mitmetele kitsaskohtadele, kuid tunnistatud ka kaasamise positiivseid külgi. Kuna olemasolev info pärineb üldjuhul ainult küsimustikest või haridusvaldkonna üldstatistikast, on kaasava hariduse rakendumist lasteaedades ja koolides vaja uurida mitmekesisemate meetoditega, 
seejuures tuleb arvestada erinevate osalistega. Praktikas esinevad probleemid ja pakutavad võimalused peaksid olema aluseks õpetajakoolituse arendamisele ning asutuste töökorralduse parandamisele, et õpetaja saaks tõhusamalt kõiki lapsi õpetada. Praeguse uurimuse eesmärk on selgitada välja, kuidas mõistetakse kaasavat haridust Eesti lasteaedades ja koolides (esimene kooliaste) ning millised on õpetajate ees seisvad ülesanded ja asutuste võimalused erivajadustega õppijate kaasamisel tavaharidussüsteemi. Uurimisküsimused on järgmised.

1. Millega seostub kaasava hariduse mõiste?

2. Milliseid võimalusi nähakse kaasava hariduse edendamiseks?

3. Mille poolest erinevad kaasava haridusega seotud hoiakud lasteaias ja koolis?

4. Milliseid õppetöö korraldamise ja keskkonna kohandamise võimalusi õpetajad teavad ning mis probleeme on nad erivajadustega laste kaasamisel täheldanud?

5. Kuidas tunnevad ennast samas grupis õppijad óppetöö käigus ja vabal ajal ning mil viisil reageerib õpetaja teistest eristuvale lapsele?

Artikli aluseks on MTÜ Hea Alguse projekti „Laps turvalises haridussüsteemis: kaasamine ja sekkumine kõigi laste huvides" raames kogutud andmed. Projekti eesmärk oli edendada kaasavat haridust 40 lasteaias ja koolis üle Eesti. 2015. aasta kevadel toimus eeluuring, mille käigus selgitati välja kaasava hariduse hetkeseis, järgnesid koolitused asutuste meeskondadele ning 2015/2016. õppeaastal koolitustel õpetatu rakendamine ning järeluuring. Siinses artiklis kirjeldame uuringute tulemusi valikuliselt.

\section{Meetod}

\section{Valim}

Valimi moodustamisel pakkus MTÜ Hea Alguse projekti meeskond üle Eesti (v.a Harjumaal) lasteaedadele ja põhikoolidele võimalust osaleda kaasava hariduse koolitustel. Asutustel tuli koostada motivatsioonikiri ning projekti meeskond tegi soovijate (kokku 80 asutuse) hulgast valiku. Välja valiti 21 kooli ja 19 lasteaeda, mille hulgas oli kuus lasteaeda-põhikooli, millest neljas osales lasteaia meeskond ja kahes kooli meeskond. Kõikides õppeasutustes õppisid nii tavalised kui ka erivajadustega lapsed (enamasti tavaklassides, harvem eriklassides) (vt tabel 1). Igal asutusel paluti moodustada 3-4liikmeline meeskond, kuhu pidid kindlasti kuuluma rühma- või klassiõpetaja, tugispetsialist ja juhtkonna liige. Projekti kaastöötajad koolitasid meeskondi mitmesugustel kaasava haridusega seotud teemadel ja osalejatel oli kohustus saadud teavet kas lasteaias või koolis levitada. 
Tabel 1. Uuringus osalenud lasteaedade ja koolide õppijad

\begin{tabular}{l|c|c|c|c}
\hline \multirow{2}{*}{ Õppijad } & \multicolumn{2}{|c|}{$\begin{array}{c}\text { Lasteaed } \\
(N=19)\end{array}$} & \multicolumn{2}{c}{$\begin{array}{c}\text { Kool (I kooliaste) } \\
(N=21)\end{array}$} \\
\cline { 2 - 5 } & Min-max & $M$ & Min-max & $M$ \\
\hline Õppijate koguarv asutuses & $20-269$ & 137,5 & $20-300$ & 106,6 \\
\hline $\begin{array}{l}\text { Erivajadustega laste koguarv asutuses } \\
\text { juhtkonna liikmete hinnangul }\end{array}$ & $2-51$ & 18,2 & $2-53$ & 22,5 \\
\hline Laste arv rühmas või klassis & $12-23$ & 19,3 & $8-26$ & 18,4 \\
\hline $\begin{array}{l}\text { Erivajadustega laste arv rühmas või } \\
\text { klassis õpetaja hinnangul }\end{array}$ & $0-12$ & 3,3 & $0-10$ & 3,4 \\
\hline
\end{tabular}

Tabelist 1 on näha, et õppijate ja erivajadustega laste arv lasteaedades ja esimeses kooliastmes, rühmades ning klassides oluliselt ei erinenud. Juhtkonna liikmete hinnangul oli erivajadustega õppijate osakaal lasteaias 13\% ja esimeses kooliastmes $21 \%$. Õpetajad märkisid küsimustikus, et keskmiselt on õppijate hulgas rühmas/klassis kolm erivajadustega last. Vaid üksikud ópetajad valisid variandi, et neil pole praegu grupis ühtegi erivajadustega last.

Erivajaduste liike küsimustikus ette ei antud: vastajad said vabalt otsustada, keda nad erivajadustega õppijateks peavad (küsimus „Millised erivajadused lapsel/lastel on?"). Erivajadustega laps lasteaias oli õpetaja hinnangul see, kel esinevad käitumisprobleemid (märgiti 11 lapsel), kõne arengu mahajäämus (9), segatüüpi erivajadused (7), muukeelsus (5), autismispektrihäired (4), õpiraskused või vaimne mahajäämus (3). Erivajadustena käsitleti ka lapsel esinevat allergiat (3) ja enneaegset sündimist (2). Koolis märgiti erivajadustega õpilastena neid, kel esinevad psühholoogilised, keskendumis- ja käitumisprobleemid (märgiti 22 õpilasel), õpiraskused (sh IÕKi, LÕKi rakendamine, 20 õpilasel), andekus (7), kõneprobleemid (3), autismispektrihäired (2), diabeet (1) ja pärinemine mustlaste perekonnast (1).

Suurem osa (19) koolis töötavatest õpetajatest õpetas tavaklassis. Liitklassiõpetajaid oli kolm: üks töötas ópiraskustega laste liitklassiga ja teine täiendavat kunstiõpet saavate 3.-5. klassi õpilastega ning kolmas oli liitklassi muusikaõpetaja. Lasteaiaõpetajatest töötas üheksa aia-, viis liit-, kolm sõime-, üks sobitus- ja üks erirühmas. Enamasti vastas õpetajate haridus küsimustiku andmetel kvalifikatsiooninõuetele. Personali andmed on esitatud tabelis 2 . 
Tabel 2. Uuringus osalenud lasteaedade ja koolide personal

\begin{tabular}{|c|c|c|c|c|c|c|}
\hline & \multicolumn{3}{|c|}{ Lasteaed $(N=19)$} & \multicolumn{3}{|c|}{ Kool (I kooliaste) $(N=21)$} \\
\hline & \multirow[t]{2}{*}{ Arv } & \multicolumn{2}{|c|}{$\begin{array}{l}\text { Haridus vastab } \\
\text { kvalifikatsioonile }\end{array}$} & \multirow[t]{2}{*}{ Arv } & \multicolumn{2}{|c|}{$\begin{array}{l}\text { Haridus vastab } \\
\text { kvalifikatsioonile }\end{array}$} \\
\hline & & täielikult & osaliselt & & täielikult & osaliselt \\
\hline Õpetaja & 19 & 18 & 1 & 21 & 17 & 4 \\
\hline Logopeed & 11 & 7 & 4 & - & & \\
\hline Eripedagoog & - & & & 4 & 4 & \\
\hline Sotsiaalpedagoog & - & & & 8 & 6 & 2 \\
\hline Psühholoog & - & & & 1 & 1 & \\
\hline Direktor & 8 & & & 4 & & \\
\hline Õppejuhataja & 11 & & & 18 & & \\
\hline Kokku & 49 & 25 & 5 & 56 & 28 & 6 \\
\hline
\end{tabular}

Tugispetsialistide seas ilmnes lasteaia ja kooli vahel sisuline erinevus: lasteaedades oli pisut üle pooltel juhtudel koolitatavasse meeskonda kaasatud logopeed, koolides olid esindatud sotsiaalpedagoog, eripedagoog või psühholoog. Juhtkonna liikmetest osalesid sagedamini õppejuhatajad.

\section{Hindamisvahendid}

Artiklis kasutame enne koolitusi kogutud küsitlus- ja vaatlusandmeid ning koolituste järel asutuste koostatud kaasamise edendamise kavadest saadud informatsiooni. Iga asutuse õpetaja, tugispetsialist ja juhtkonna liige täitis kirjaliku küsimustiku, mis oli koostatud erinevate tudengiuurimuste ning teoreetilise kirjanduse alusel koolidele ja lasteaedadele eraldi (enamik küsimusi kattus sisu poolest). Küsimused puudutasid vastaja ja rühma/klassi või asutuse üldandmeid, töökorraldust, kasvukeskkonna kohandamist ja meeskonnatööd.

Õppetöö vaatluse protokoll koosnes kahest osast: üldandmetest ja tabelist, kuhu märgiti käitumise esinemissagedus. Vaatleja ülesanne oli jälgida õppetööd ning märkida üles, missuguse käitumise poolest mõni laps grupist eristus. Seejärel tuli teha märge iga korra kohta, kui teistest eristuv laps paistis end tundvat halvasti või teised lapsed käitusid, nagu neil oleks raske/halb olla. Paralleelselt tuli märkmeid teha ka selle kohta, kui õpetaja väljendas oma suhtumist eristuvasse õppijasse kas positiivselt või negatiivselt. 
Lasteaedade ja koolide meeskonnad koostasid kaasamise edendamise kavad, lähtudes etteantud struktuurist. Igas asutuses oli vaja kaasamise teemal arutleda ning teha plaanid konkreetseks õppeaastaks, täpsemalt (tegevus, aeg, vastutaja) kolmeks kuuks.

\section{Protseduur}

Eeluuring toimus aprillis ja mais 2015. Projekti koordinaator leppis asutuste kontaktisikutega kokku eeluuringu toimumise aja, kestuse ja korralduslikud tingimused. Asutustes käis korraga kaks uurijat: esmalt vaatlesid nad korraga üksteisest sõltumatult ühte õppetegevust/tundi ja vaba aega / vahetundi (kokku 60 minutit) ning seejärel täitsid kolm töötajat küsimustikud (60 minutit). Õpetaja ei saanud infot, mida täpselt vaadeldakse, kuid teadis, mis projekti raames seda tehakse. Küsimustikud olid paberil ning neid täideti individuaalselt samas ruumis uurijatega kohe pärast vaatlust.

Eeluuringu järel toimusid asutuste meeskondade ühiskoolitused (kolm ja kaks päeva) lasteaedadele ja koolidele korraga. Koolitustel käsitleti järgmisi teemasid: lapsekeskne õppeprotsess, loovusel ja aktiivsel tegutsemisel põhinevad grupiviisilised sekkumismeetodid, õppekeskkond ja pedagoogiline analüüs (LP mudel), koostööoskused. Siinkirjutajad koolitustega seotud ei olnud.

Järeluuringu raames septembris 2015 paluti osalejatel koostada kaasamise edendamise kava 2015/2016. õppeaastaks oma asutuses. Kes ja kuidas selle kava koostamisel osales, ei reguleeritud. Realistlikkuse tagamiseks märgiti juhendis, et detsembris-jaanuaris järgnevad asutuste külastused planeeritu arutamiseks. Kaasamise edendamise kavad laekusid 34 asutuselt (loobusid neli kooli ja kaks lasteaeda) oktoobris e-kirja teel. Uuringu etapid koos uurimisküsimustega on esitatud joonisel 1.
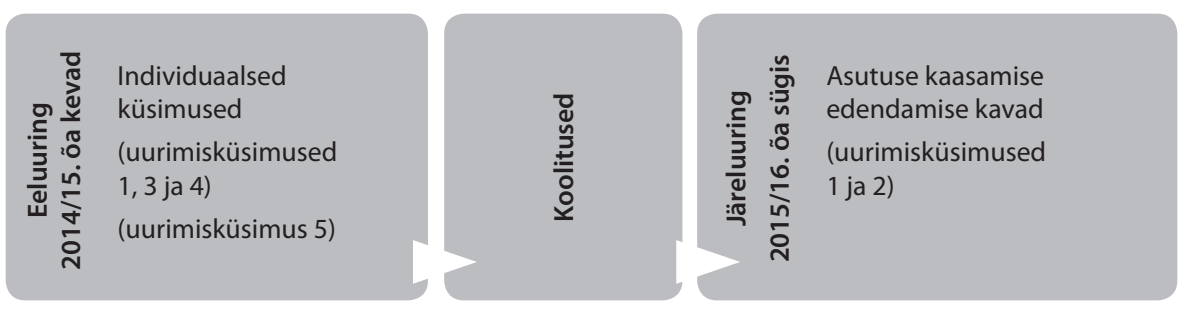

Joonis 1. Uuringu etapid 


\section{Andmeanalüius}

Kvantitatiivsete andmete analüüsiks tehti statistikapaketi SPSS 23 abil kirjeldav statistiline analüüs ning võrreldi eri gruppide keskmisi tulemusi, kasutades Likerti skaalal esitatud andmete puhul Manni-Whitney U-testi ning loendamisel saadud andmete puhul $t$-testi. Et analüüsida avatud küsimuste vastuseid ning kaasava hariduse edendamise kavades sisalduvat infot, tehti kvalitatiivne sisuanalüüs: pärast induktiivset kodeerimist moodustati kategooriad ja vajaduse korral alamkategooriad. Kvalitatiivseid andmeid analüüsisid autorid teineteisest sõltumatult, erinevuste korral jõuti hilisema arutluse käigus konsensusele.

\section{Tulemused ja arutelu}

\section{Kaasava hariduse mõistmine}

\section{Individuaalne arusaam}

Eeluuringu käigus paluti õpetajatel, tugispetsialistidel ja juhtkonna liikmetel individuaalselt sõnastada, mis on nende arvates kaasav haridus. See mõiste seostus vastajatele eeskätt kõikide laste koos õpetamise ja individuaalse lähenemisviisiga, mille kõrval märgiti veel tugisüsteemi rolli ning koostööd perekonnaga. Samas ei olnud paljudel juhtudel erivajadustega laste kaasamist sõnaselgelt mainitud ning mõne definitsiooni puhul oli raske mõista, kas kirjutaja on silmas pidanud erivajadustega või erivajadusteta lapsi.

Igal lapsel on õigus käia talle kodulähedases koolis. (Juhtkonna liige, kool)

Kirjapandust võib arvata, et iga lapse all mõistetakse nii tavalisi kui ka erivajadustega lapsi, kuid liiga üldsõnaline esitusviis ei välista teistsuguseid tõlgendusvõimalusi. Lisaks ilmnes, et kaasavat haridust võib mõista tavapärasest erinevalt, nähes sellena kõike, mis suurendab õppija aktiivsust.

Kaasa tõmbav haridus, kus lapsed saavad aktiivselt osaleda, selle abil õpib laps osalusdemokraatiat. (Juhtkonna liige, lasteaed)

Kaasab erinevaid õppeaineid ja ka üldiselt eluvaldkondi, õppemetoodikaid. (Õpetaja, kool)

Kõikide laste koos õpetamist mõistsid lasteaia- ja koolitöötajad veidi erinevalt. Kui lasteaednike puhul tähendas koos õpetamine seda, et samas rühmas olid nii tavalised kui ka erivajadustega lapsed, siis kooli puhul ilmnes kaks käsitusviisi: erinevad lapsed võisid olla samas klassis või samas koolis. 
Kaasava hariduse puhul osalevad eakaaslastega ühes tunnis ka erivajadustega õpilased. (Õpetaja, kool)

Kõik õpilased õpivad tavakoolis, nad on kaasatud (ei õpi erikoolis).

(Juhtkonna liige, kool)

Individuaalse lähenemisviisi puhul eristusid alamkategooriatena lastele võimetekohaseks arenguks tingimuste loomine ja laste vajadustega arvestamine. Viimasele osutasid ainult juhtkonna liikmed.

Erivajadustega laste õpetamisel koos tavaliste lastega rõhutati vajadust tugisüsteemide järele, seda eriti siis, kui kaasavat haridust defineeriti erivajadustega laste keskselt. Mõnel juhul nähti tugispetsialisti lisaressursina, kes aitab kaasa erivajadustega lapse arengule. Lapsevanemaid nimetati koos tugispetsialistidega kui lapse arengu toetajaid.

Laste arendamine koostöös lastevanemate ja erinevate tugisüsteemidega. (Õpetaja, lasteaed)

Ideaalis on kaasav haridus erivajadusega lapse õpetamine ja arendamine tavarühma tingimustes, kus on loodud lapse arengut toetav keskkond ja kaasatud tugispetsialistid. (Tugispetsialist, lasteaed)

Õpilastele hariduse andmine vastavalt tema võimetele, individuaalne lähenemine, koostöö tugispetsialistide ja koduga. (Õpetaja, kool)

\section{Ühine arusaam}

Kaasava hariduse edendamise kavades, mis koostati pärast meeskondade ühiskoolitusi asutuse tasandil, hõlmas kaasav haridus erivajadustega õppijaid suuremal määral ning selgitused olid eeluuringuga võrreldes detailsemad. Kaasav haridus tähendas tavaliste ja erivajadustega laste koos õppimist, individuaalset lähenemist neile ja tugisüsteeme, kuid nimetati ka muid kaasamist mõjutavaid tegureid, näiteks õpetajate oskused ja hoiakud, asutuse personali meeskonnatöö, kaasamist toetavate metoodikate (KiVa, Hea Alguse metoodika) kasutamine, toetav juhtkond. Rõhutati koostööd lapsevanemate või kogukonnaga. Mõnikord toodi kaasavast haridusest rääkides välja üldisemalt õppekorraldusega seotud teemad, nagu tasemerühmades õpetamine, numbrilise hindamise puudumine, aktiivõppe meetodite kasutamine või arenguvestlused. 


\section{Kaasava hariduse edendamise võimalused}

2015/2016. õppeaastaks plaaniti rakendada lasteaedades ja koolides kaasavat haridust laiemalt ning kasutada olemasolevaid võimalusi paremini ära, et toetada seeläbi kõiki õppijaid. Kaasamise edendamise kava, mille koostas projekti koolituste järel asutuse meeskond üheskoos, koosnes kolmest osast: 1) õpetaja töö rühmas või klassis; 2) töökorraldus asutuses; 3) koostöö asutusest väljaspool.

\section{Õpetaja töö}

Õpetaja tööd puudutavad meetmed jagunesid kaheks: need, mis olid suunatud õpetaja teadmiste ja oskuste täiendamisele, ja need, mis soodustasid meeskonnatööd.

Kuna alustada on vaja üsna algusest, siis panustame kõigepealt õpetajate koolitusse. (Kool)

Ühistes aruteludes õpetajatega viia sisse mõte, et kõik lasteaia laste mured on meie ühised probleemid ja lahenduse proovime leida üheskoos. (Lasteaed)

Samamoodi nagu eeluuringus, mainiti ka järeluuringus kaasava haridusega seoses individuaalset lähenemist lapsele. Laste vajaduste ja võimetega arvestamist kirjeldati üldsõnalisemalt, seevastu keskendumine kitsamalt erivajadustega lastele oli sõnastatud konkreetsemalt.

IAKd ja individuaalsed tegevused lastega. (Lasteaed)

Vajadusel rakendame individuaalset tunniplaani, individuaalset õppimist, tegevusi vastavalt õpilase individuaalsusele ja vajadustele. (Kool)

Õpetaja tööga seostus ka plaan toetada laste sotsiaal-emotsionaalset või vaimset arengut, siduda klassikollektiiv tervikuks ja muuta füüsilist keskkonda õppimiseks sobivamaks.

\section{Korralduslikud muudatused}

Asutuste meeskonnad kavandasid mitmesuguseid korralduslikke muudatusi. Üks võimalus oli õpetada erivajadustega lapsi koos kõigi teistega samas klassis või lasteaia sobitusrühmas.

LÕK-õpilased ja liikumispuudega õpilane õpivad tavaklassis, nad on kaasatud ka klassi- ja kooliüritustele. (Kool)

Lasteaias on loodud sobitusrühm. (Lasteaed) 
Teise võimalusena nähti erinevate õpilaste õpetamist samas asutuses, kuid eraldi klassis või rühmas. Nii puutuvad kõik lapsed siiski omavahel kokku lasteaia õuealal või kooli ühisüritustel.

Õueala ei ole rühmiti piiratud ning erirühma lapsed on kaasatud kõikide laste mängudesse. (Lasteaed)

Antud hetkel meie koolis on kaasatud õppeprotsessi ja ühisüritustesse kõik õpilased, ka need, kes võiksid käia erikoolides. Oleme oma koolis loonud LÕK-õpperühmad, keelekümblusrühmad ning väikeklassid. (Kool)

Kolmas võimalus, millele osutasid koolide meeskonnad, oli erivajadustega õpilaste õpetamine mõnes aines eraldi tavalistest õpilastest ja mõnes koos nendega.

Tavaklasside kõrval on väike- ja õpiraskustega laste klass, mille õpilased osalevad oskusainetes tavaklassi tundides. (Kool)

\section{Tugisüsteemid ja koostöö}

Kaasava haridusega seostusid tugisüsteemid ja koostöö nii asutuse sees (nimetati psühholoogi, logopeedi, sotsiaalpedagoogi, meditsiiniõde, abiõpetajat, HEV-koordinaatorit) kui ka asutusest väljaspool. Koostööd sooviti arendada laste vahel, õpetajate vahel, kogu asutuse personaliga ja/või asutusest väljaspool olevate isikute või institutsioonidega (Rajaleidja keskused või kogukond). Eraldi toodi välja kaasavat haridust soodustav LP mudel, millega tutvuti projekti raames korraldatud koolitustel. Koolid mainisid ka kavatsust tihendada koostööd koolieelse lasteasutuse või sama asutuse lasteaia-osaga.

Tihendame koostööd valla lasteaedadega, kaasame kindlasti ka valla lasteaedade logopeedi, et koos pakkuda kõigile lastele turvalist õppimist ja edendada koos sarnaselt kaasava hariduse põhimõtteid lasteaiast kooli. (Kool)

Lapsevanemaid nähakse koostööpartneritena, keda soovitakse kaasata rühma/klassi tegemistesse või probleemide lahendamisse, või nõu ja abi vajajatena, keda tuleks toetada ja nõustada ning kellele pakkuda koolitusi. Esimesel juhul märgiti lapse arengu edendamise nimel tehtavat koostööd, mis võib seisneda selles, et vanem külastab kooli või rühma (mis võivad, aga ei pruugi hõlmata erivajadustega lapsi). Teisel juhul nägid lasteasutuse pedagoogid end vanemate koolitajate rollis. 
Lapsevanematest on saanud toetavad ja nõuandvad partnerid. (Kool)

Perede ja personali nõustamine (ümarlaud). (Lasteaed)

Kaasava hariduse mõiste oli kokkuvõttes üsnagi lai, samas käsitati seda lasteaias ja koolis sarnaselt. Eeluuringu küsimustikus paiknes küsimus kaasava hariduse kohta sisulise osa alguses, mis tähendab, et küsimustiku järgmised osad ei saanud veel mõjutada vastaja arusaama. Samuti ei olnud ette nähtud küsimuse arutamist teistega. Ka Fullan (2006) soovitab esmalt sõnastada individuaalsed arusaamad, seejärel liikuda sealt edasi ühise seisukoha kujundamise suunas. Kaasamise edendamise kavades tuli saavutada üksmeel asutuse tasandil, mis tõi ootuspäraselt kaasa läbikaalutuma ja konkreetsema sõnastuse, täpsustatud tegevused ning rollijaotuse (Jones, 2004). Raamistiku kavandatud muudatustele annab riigi hariduspoliitika (Haridus- ja Teadusministeerium, 2013; Loreman et al., 2014) ning valdkonnas võimalikud ressursid, nt inimesed, vahendid, aeg (Balti Uuringute Instituut, 2015).

\section{Kaasamisega seotud hoiakud lasteaias ja koolis}

Erivajadustega lapse kaasamise kohta esitati asutuste meeskondadele eeluuringu küsimustikes mitmeid väiteid ning paluti hinnata, kuivõrd õigeks neid peetakse (hinnangud viiepallisel Likerti skaalal: „Ei ole nõus”, „Pigem ei ole nõus”, „Pigem olen nõus”, „Olen nõus”, „Ei oska öelda”). Tulemused kodeerisime ümber nii, et jäi alles neli sisulist skaalapunkti, st „Ei oska öelda" muudeti puuduvaks vastuseks. Analüüsisime nii õpetajate, tugispetsialistide kui ka juhtkonna liikmete vastuseid. Järgnevalt on toodud väited, millega nõustuti lasteaias ja koolis erineval määral.

Väite „Lapse arengu toetamise eest asutuses vastutavad logopeed, psühholoog, sotsiaalpedagoog ja eripedagoog" korral ilmnes koolide ja lasteaedade töötajate vahel statistiliselt oluline erinevus $(p=0,002)$. Kooli töötajad nõustusid nimetatud väitega rohkem kui lasteaia töötajad. Sama tendents ilmnes ainult õpetajaid vaatluse alla võttes: kui 19 lasteaiaõpetajast nõustus selle väitega suuremal või vähemal määral 7, siis 21st koolis töötavast õpetajast oli sama meelt 15 . Lasteaedades töötasid tugispetsialistidena ainult logopeedid, kelle põhiülesanne on tegeleda kõneprobleemidega. Koolides on tugispetsialiste rohkem, mistõttu võibki tunduda, et nemad ühiselt võtavad kogu vastutuse enda kanda. Sarnasele järeldusele on jõutud ka välismaistes uuringutes (Pecek et al., 2008).

Väite „Erivajadustega laste õpetamine tavaliste laste hulgas tähendab õpetaja jaoks lisatööd väljaspool rühmategevusi/klassitunde" puhul väljendasid 
kooli töötajad tugevamini oma nõusolekut kui nende lasteaias töötavad kolleegid $(p=0,007)$. Mida nooremate ja üksteisest erinevamate lastega õpetaja tegeleb, seda enam on tal vaja olla valmis individuaalseks tööks. Koolis nähtavasti eeldab õpetaja, et laps ise pingutab enam ning suudab valdavalt õppida juba koos teistega. Erivajaduste korral vajab laps siiski enam abi. Lasteaiaõpetajate mõnevõrra soodsamale meelestatusele erivajadustega laste kaasamise suhtes on osutanud ka Bendová jt (2014) ning Lee jt (2015).

Väitega „Laste poolt tehtud vigade analüüsimisele ei ole mõtet aega kulutada, sest lapsed teevad oma töödes alati vigu ja õppimise käigus nende hulk enamasti väheneb" nõustuti koolis vähem kui lasteaias $(p<0,001)$. Vaadeldes õpetajaid ning jättes kõrvale tugispetsialistid ja juhtkonna liikmed, selgus, et koolis töötavad õpetajad peavad laste tehtud vigadele tähelepanu pööramist ja vigade analüüsi olulisemaks, kui seda teevad nende lasteaias töötavad kolleegid $(p=0,002)$. Vigade analüüsi peetakse (eri)pedagoogikas üheks parimaks võimaluseks aru saada, mis on lapsele raske ehk mida tuleb juurde õpetada (vt ka Hattie, 2012).

Väitega „Lapse õppimis- ja käitumisprobleemide korral on oluline lapsevanemaid kõikidest probleemidest alati teavitada" oli lasteaias nõustujaid rohkem kui koolis $(p=0,011)$. Koolieelses eas on alushariduse eest vastutaja lapsevanem (Koolieelse lasteasutuse seadus, 1999), koolieas jagatakse seda vastutust enam kooli personali ja õpilase endaga.

Väitega „Erivajadustega laps saab tavaliste laste hulgas õppida juhul, kui tal on kaasas tugiisik või eraldi abiõpetaja" nõustuti koolis vähem kui lasteaias $(p=0,005)$. Lasteaias kaasatakse tõenäoliselt laiemat hulka erivajadustega lapsi, sh ka suurema abivajadusega lapsi, kelle turvalisust on raske tagada kuni 24liikmelises rühmas, sest lapsed ise ei juhi enda käitumist tõhusalt (Tropp \& Saat, 2008) ega oska end kaitsta. Vajadust väiksema laste arvu ning abistava personali suurendamise järele on välja toodud ka varasemates õpetajate küsitlustes (Bendová et al., 2014; Eha, 2010; Kruusamäe, 2015; Lee et al., 2015; Postak, 2015).

Lasteaia ja kooli vahel ilmnenud hoiakute erinevusi saab valdavalt seletada õppijate, personali ning keskkonna spetsiifikaga. Lasteaiaeas alles selgitatakse välja, kas ja missuguste erivajadustega laps on. Peale õppetöö moodustavad suure osa lasteaialaste päevast mäng, õueaeg ja magamine, lisaks on õpetajale toeks õpetaja abi. Koolis on õpetajal kindel arv tunde ja ta tegutseb sel ajal valdavalt üksi. Koolis peale tunde jäämine on selgemalt lisatöö kui lasteaias päeva jooksul mõne lapse jaoks aja võtmine. Seega paistavad lasteaias olevat kaasava hariduse rakendamiseks soodsamad tingimused, sh personali hoiakud. 


\section{Õpetaja ees seisvad ülesanded}

\section{Keskkonna kohandamise võimalused, õpetamine}

Õpetaja kutsestandardites (Kollom et al., 2013; Pedaste et al., 2013) on välja toodud, et õpetaja loob üksteist arvestava õpikeskkonna, valib õpetamiseks ja õppimiseks sobivad meetodid ning õppevara. Eeluuringus küsisime õpetajatelt kõigepealt, mis võimalusi keskkonna kohandamiseks nad teavad ning milline õpetamine on levinud.

Füüsilise keskkonna muutmise võimalusi näevad nii lasteaia- kui ka kooliõpetajad sageli mööbli ümberpaigutamises või sobivama mööbli hankimises - enam kui pooled sellele küsimusele vastanutest nimetasid ühe või ainsa võimalusena mööblit. Ühe keskkonna kohandamise võimalusena toodi välja lastele üksi olemise nurga loomine. Küsitluse andmetest selgus, et koolis on praegu peamiseks eraldumisvõimaluseks tugispetsialisti kabinet, mida nimetasid kümme õpetajat, seevastu neljas koolis polnud lastel võimalust eralduda. Lasteaedades oli eraldumiseks kohti rohkem, kõige sagedamini nimetatud kohad olid lugemisnurk, magamistuba, riideruum (kõiki nimetas 13 õpetajat 19st). Muudetavate füüsilise keskkonna teguritena märgiti veel tegeluskeskuste tekitamist, täiendavate õppe- või tegevuspaikade leidmist samas hoones või sellest väljaspool. Keskkonna kohandamiseks pakub õpetajate arvates võimalusi ka müra vähendamine (selleks saab vahetunnis õpilastele huvitavaid tegevusi pakkuda) või ruumi muutmine rahulikumaks (valida mitteärritavad värvid rühmaruumis, asjade küllus - laste silma alt ära panna asjad, mis tekitavad temas segadust) või huvipakkuvamaks (palju näitlikustavaid vahendeid seintele).

Sotsiaalse keskkonna muutmise võimalustena nähti heade suhete kujundamist nii kolleegide, laste kui ka õpetajate ja laste vahel. Lastevaheliste suhete arendamiseks sobivad laste ühismängud, üksteisega arvestamist nõudvad tegevused, rühmatööd. Täiskasvanud peaksid andma lastele oma käitumisega head eeskuju, suhtudes mõistvalt inimeste erinevustesse. Lapsi tuleks tunnustada ja positiivset käitumist esile tuua, et selline käitumine kujuneks normiks. Sotsiaalsete tegurite hulgas toodi välja ka laste arvu vähendamine või täiskasvanute arvu suurendamine lasteaiarühmas.

Tänapäevaste seisukohtade järgi ei ole võimalik lapse arengut ja õppimist muuta n-ö teadmisi pähe pannes, vaid me saame üksnes luua tingimused, et laps areneks ja õpiks. Nii tuleb õpetajal olla teadlik, loov ja paindlik, varieerides erinevaid füüsilise ja sotsiaalse keskkonna tegureid (Dmitrieva \& Nartova-Bochaver, 2014; Häidkind et al., 2013; Schwab, 2015). Küsitlusest selgus paraku küllaltki kitsas ja ühetaoline arusaam sellest, mida on võimalik muuta. Üldse ei puudutatud näiteks materjali mahtu, tegevuste 
kestust, abistamise määra. Nähtavasti neid tegureid varieeritakse, aga endale ei teadvustata piisavalt, et valik on oluliselt laiem kui keskendumine mööblile.

Õpetaja otsustab, mis õpetamise vormid, meetodid ja vahendid ta valib konkreetse teema jaoks püstitatud eesmärkide täitmiseks. Küsisime, mis vormis (millise suurusega gruppides) viivad õpetajad läbi õppetegevusi oma rühmas. Mõned õpetajad nii lasteaias kui ka koolis märkisid, et õpetavad kogu rühma või klassi üheskoos. Teine nimetatud võimalus oli õpetada lapsi gruppides - nii 2-3liikmelistes väikegruppides kui ka poolt klassi või rühma hõlmavates gruppides. Lasteaia puhul toodi välja rühma jagamine kaheks grupiks laste vanuse järgi. Kolmandaks võimaluseks oli individuaalne töö lapsega kas individuaalsete koolitundidena või peale tunde. Arvatavasti tehakse ka lasteaias osa individuaalsest tööst enne/pärast tegevuse läbiviimist teiste lastega, kuid õpetajad sellele eraldi ei osutanud. Neljas võimalus on mõnede õppeainete õpetamine või mõnede tegevuste (nt käeliste tegevuste) tegemine alati gruppides, samal ajal kui ülejäänud õppetöö toimub kogu klassil või rühmal koos.

Küsisime, mis õppemeetodeid rühmas sagedamini rakendatakse. Sagedamini kasutatavad õppemeetodid võib jagada vaatlemiseks ja näitlikustamiseks (vaatlemine, ettenäitamine, näitvahendite või mõistekaartide kasutamine), vestlemiseks ja arutlemiseks (vestlus, jutustamine, dialoogid, arutlus), aktiivseks tegutsemiseks (mängimine, avastusõpe, aktiivõpe, rollimäng, dramatiseering). Üks lasteaiaõpetaja märkis meetodina ka muusikaõpet (laulame palju). Eraldi rühmana eristusid eelnimetatutest terviklikud metoodikad, mida õpetajad väitsid end kasutavat: Hea Alguse metoodika, keelekümblus, J. Käisi meetodid, Waldorfi metoodika. Siia rühma võiks lisada ka eraldi nimetatud õuesõppe ja projektõppe.

Õppematerjalide valikul lähtuvad nii koolis kui ka lasteaias töötavad õpetajad materjalide sobivusest laste arengutasemega, laste huvist ja õppekavast. Koolis töötavad õpetajad võtavad enda sõnul õppematerjale valides arvesse lisaks koolis kasutusel olevat õpikut ning õpilaste meeleolu ja väsimust.

Õpetamisega seotud küsimuste vastustest ilmnes, et üldiselt õpetajad teavad, kuidas luua õppimiseks soodsaid tingimusi klassis/rühmas. Enamik õpetajatest hindas oma haridust kvalifikatsioonile vastavaks (vt tabel 2) ja tulemuste alusel võib järeldada, et eakohaselt arenevate laste õpetamise jaoks vajalikud teadmised olid neil olemas. 


\section{Õppetöö probleemid seoses erivajadustega lastega}

Peaaegu kõikidel õpetajatel oli nende endi hinnangul rühmas/klassis erivajadustega õppijaid, st kogemus oli olemas (Oras, 2003; Spratt \& Florian, 2014). Seetõttu küsisime õpetajatelt, millised on need õppetöö probleemid, mis on erivajadustega lapse (laste) tõttu rühmas/klassis tekkinud. Selgus, et kogetud on laste käitumise, õppimise ja õppekorraldusega seotud probleeme. Lapse käitumisega seotud probleemid väljenduvad näiteks lapse suutmatuses paigal püsida, teiste laste keskendumist häirivas sihitus tegutsemises, õppetegevuse tahtlikus segamises. Õppimisega seotud probleemid avalduvad koolis ja lasteaias mõnevõrra erineval moel. Kui koolis olid õpetajad märkinud ära õpilase õpiraskused või kaaslastest erineva töötempo, siis lasteaias oli suur hulk eelnimetatud probleemidest seotud lapse kõne arenguga (ei kasuta kõnes kõiki häälikuid, laps ei suhtle, väike sõnavara, probleemiks on kõne mõistmine, kõne nõrkus). Nii koolis kui ka lasteaias osutati lapse raskustele töökäskudest või ülesannetest arusaamisega. Õppekorralduslikud probleemid koolis olid õppevahendite puudumine ja sobimatus, tugispetsialistide vähesus ning liiga suur erivajadustega õpilaste arv. Lasteaias toodi välja, et erivajadustega lapsega tegelemine väsitab õpetajat emotsionaalselt ning seetõttu ei saa teised lapsed piisavalt tähelepanu.

Kui analüüsida koos nii õpetajate nimetatud keskkonna kohandamise võimalusi, õpetamise aspekte kui ka erivajadustega õppijatest tulenevaid probleeme, tundub, et nii mõnedki probleemid oleksid lahendatavad lähenemisviiside kohandamisega. Selle kohta, miks, mida, millal ja kuidas õpetamises muuta, kui grupis on erivajadustega õppija, vajavad õpetajad senisest paremat või põhjalikumat ettevalmistust ja asutused lisaressursse (Balti Uuringute Instituut, 2015; Euroopa Eripedagoogika Arendamise Agentuur, 2011; Hornby, 2014; Karlep, 2015). Ei piisa ainult kogemusest, pedagoogilisest kompetentsist, vaid näiteks lasteaia sobitusrühma õpetajal peab olema ka eripedagoogiline kompetents (Koolieelse lasteasutuse pedagoogide kvalifikatsiooninõuded, 2013).

\section{Õppetöö vaatluse andmed}

Õpetaja, kelle kohta olid olemas küsitlusandmed, näitas kahele vaatlejale oma igapäevast õppetööd rühmas või klassis. Õppetööd ja vaba aega / vahetundi vaadeldi ette antud vaatlusprotokolli alusel.

Vaatlejate hinnangul eristus klassis või rühmas (grupis) keskmiselt 1-2 last. Asutuste puhul oli varieeruvus suur: mõnes grupis ei eristunud ükski laps, suurim eristuvate laste arv ühes vaadeldud grupis oli viis. Koolieelses lasteasutuses oli eristuvaid lapsi rühmas keskmiselt rohkem $(1,59)$ kui 
kooliklassis $(1,28)$, kuid erinevus ei olnud statistiliselt oluline. Lapsed eristusid vaatlejate jaoks nii lasteaias kui ka koolis kolme tüüpi tunnuste alusel: väljapoole suunatud käitumisprobleemid (rahutud, aktiivsed, püsimatud, jonnakad, segavad, domineerivad, hajuva tähelepanuga), sissepoole suunatud käitumisprobleemid (kinnised, arad, hoiavad omaette, ei suhtle, ei osale), õppimisel suur vajadus abi järele (vajavad individuaalset lähenemist, abi, nõrgad, kohmakad, aeglased, kõneprobleemidega).

Üheks vaatlusülesandeks oli märkida, mitmel korral tundus, et tavaarenguga või teistest eristuval lapsel oli raske/halb olla. Tavalised lapsed paistsid end halvasti tundvat keskmiselt 1,27 korral, teistest eristuvad lapsed keskmiselt 1,16 korral. Võrreldes kooli ja lasteaeda, selgus, et vabal ajal oli tavalistel lastel koolieelses lasteasutuses sagedamini halb olla kui koolis (keskmiselt vastavalt 0,53 ja 0,15 korda vaadeldud aja jooksul, $p=0,011$ ). Õppetegevuse ajal asutuste vahel niisugust erinevust ei ilmnenud.

Vaadeldes õpetaja tegevust, selgus, et kooli- ja lasteaiaõpetajad pöörasid teistest eristuvale lapsele sagedamini nii positiivset kui ka negatiivset tähelepanu: esimest keskmiselt 1,53 korda, teist 0,48 korda. Paarisvalimi $t$-test näitas, et see erinevus on statistiliselt oluline $(p<0,001)$. Oluline erinevus kooli ja lasteaia vahel ilmnes teistest eristuva lapse suunamises ja innustamises vabal ajal $(p<0,001)$, mida tuli samuti oluliselt sagedamini ette koolieelses lasteasutuses (keskmiselt 0,64 korda) kui koolis (keskmiselt 0,03 korda). Asutustel paluti näidata tavapärast õppetegevust või tundi, aga õpetaja teadis, et vaadeldakse kaasava hariduse projekti raames. Seega võib arvata, et erivajadustega laste vastu ilmutasid õpetajad mõnevõrra suuremat tähelepanu kui tavaliselt, ilma vaatlusolukorrata. Eripära väljendus enam lasteaias kui koolis.

Kaasav haridus tähendab, et võidavad kõik õppijad. Seega seisab õpetaja silmitsi keerulise ülesandega luua niisugune õhkkond, kus iga grupi liige tunneb end piisavalt turvaliselt, saab nii jõukohaselt pingutada kui ka vajalikul määral tähelepanu ja tunnustust. Selle saavutamisse tasub panustada (vt Säälik et al., 2013; Übius et al., 2014).

\section{Järeldused}

Kaasava hariduse mõistet defineeritakse Eestis nii kitsamalt (erivajadustega laste õpetamine teistega koos) kui ka laiemalt (kõikide õigus õppida elukohajärgses haridusasutuses). Kaasava hariduse edendamiseks nähakse mitmesuguseid võimalusi, mis hõlmavad näiteks asutuse töökorralduse muutmist, osalistevahelise koostöö tõhustamist ja õpetajate täiendkoolitusi. Lasteaia personali hoiakud kaasamise suhtes on positiivsemad kui 
koolis, klassiõpetajad pidasid erivajadustega õppija toetamist sagedamini tugispetsialistide vastutusalasse kuuluvaks ülesandeks. Tavaliste laste õpetamiseks on õpetajad küsitluse alusel piisavalt pädevad, kuid erivajadustega laste kaasamisel kogetakse raskusi seoses laste käitumise ja õppimise probleemidega ning õppekorraldusega. Võib öelda, et Eestis ollakse kaasamise tee keskpaiga lähedal, st tavakeskkonnas püütakse erivajadustega õppijatele kohaldada mitmesuguseid tugimeetmeid (Euroopa Eripedagoogika Arendamise Agentuur, 2009), kindlustunnet selles nähtavasti saavutatud ei ole (Haridus- ja Teadusministeerium, 2015). Seetõttu võiksid uurimistulemused osutuda kasulikuks õpetajakoolituse korraldamisel.

Kaasava hariduse arendamiseks ehk hariduse kvaliteedi parandamiseks on kõrgkoolides vaja käsitleda järgmisi teemasid.

- Kaasava hariduse olemus ja eesmärk. Tegemist on kompleksse teemaga, mis hargneb erinevate sihtrühmade ja tegevuste suunas (seadustest tulenevad tugimeetmed lasteaias ja koolis).

- Koosolemise ja -õppimise erinevus. Kaasavat haridust käsitletakse kohati ainult sotsiaalse kaasamise tähenduses (ühised üritused, huviringid jne), kuid koosõppimine eeldab õpetajalt individuaalset lähenemist õppijale ning jõukohase töö kavandamist ja realiseerimist, lähtudes laste tasemest. Praegune uurimus õpetuse kvaliteedi kohta järeldusi teha ei võimalda.

- Erivajaduste liigid õpetaja vaatenurgast. Äratundmisele lisaks on vajalik kujundada konkreetsem valmisolek õppimis- ja käitumisprobleemidega tegelemiseks, õppekorralduse kohandamiseks.

- Kasvukeskkonna kohandamise võimalused. Õpetaja vastutab, et keskkond soodustaks iga õppija arengut ja õppimist. Õpetajale on vaja tutvustada eri tüüpi tegureid, mida ta muuta saab.

- Meeskonnatöö. Niipea, kui laps eristub grupist ning õpetaja tehtud kohandustest ei piisa, tuleb ühendada inimesed, kes juhendavad õpetajat (tugispetsialistid, juhtkond), ning inimesed, kes aitavad muudatusi realiseerida (lapsevanemad, tugiisik, abiõpetaja, õpetaja abi).

Siinses uurimuses kogusime andmeid eelkõige kaasava hariduse ulatuse kohta. Lasteaedade ja koolide arvulised näitajad olid omavahel võrreldavad, erivajadustega laste osakaal uuritud asutuste rühmades/klassides langeb kokku ka üleriigilise statistikaga aastate 2012-2015 kohta. Uuringus osalenud õpetajate väljaõpe vastas nende endi hinnangul kvalifikatsiooninõuetele ning õpetajatel oli vähemalt ühe õppeaasta pikkune kogemus erivajadustega laste kaasamises. Uuringu tulemusi võib pidada üldistatavaks valimiga sarnastele asutustele ja õpetajatele. 


\section{Tänusõnad}

Uurimus valmis MTÜ Hea Alguse projekti „Laps turvalises haridussüsteemis: kaasamine ja sekkumine kõigi laste huvides" raames, mida viidi ellu aastatel 2014-2016 ning mida toetati Euroopa Majanduspiirkonna toetuste programmi „Riskilapsed ja -noored” rahalistest vahenditest.

\section{Kasutatud kirjandus}

Balti Uuringute Instituut (2015). Uuring „Õpetajate täiendusõppe vajadused”. Lõpparuanne. Külastatud aadressil http://dspace.ut.ee/bitstream/handle/10062/45196/ Opetaja_taiendoppe\%20vajadus.pdf? sequence $=1$ \&isAllowed $=\mathrm{y}$.

Bendová, P., Čecháčková, M., \& Šádková, L. (2014). Inclusive education of pre-school children with special educational needs in kindergartens. Procedia - Social and Behavioral Sciences, 112, 1014-1021.

doi: http://dx.doi.org/10.1016/j.sbspro.2014.01.1263

De Boera, A., Pijlb, S. J., \& Minnaert, A. (2011). Regular primary schoolteachers' attitudes towards inclusive education: A review of the literature. International Journal of Inclusive Education, 15(3), 331-353.

doi: http://dx.doi.org/10.1080/13603110903030089

Dmitrieva, N. S., \& Nartova-Bochaver, S. K. (2014). The opportunities of physical environment in the context of inclusive education. Psychological Science \& Education, 19(1), 74-81.

Eha, P. (2010). Õpiabisüsteemide rakendumine ja õpetajate hoiakud Järvamaa põhikoolides (magistritöö). Tartu Ülikool, Tartu. Külastatud aadressil http://dspace.ut.ee/handle/10062/15880.

Euroopa Eripedagoogika Arendamise Agentuur (2009). Juhtpõhimõtted kaasava hariduse kvaliteedi arendamisel. Soovitused poliitikakujundajatele. Odense: Euroopa Eripedagoogika Arendamise Agentuur. Külastatud aadressil https://www.european-agency.org/sites/default/files/key-principles-for-promoting-quality-ininclusive-education_key-principles-ET.pdf.

Euroopa Eripedagoogika Arendamise Agentuur (2011). Kaasamist toetav ópetajakoolitus Euroopas. Probleemid ja võimalused. Odense: Euroopa Eripedagoogika Arendamise Agentuur. Külastatud aadressil https://www.european-agency.org/sites/default/ files/te4i-challenges-and-opportunities_TE4I-Synthesis-Report-ET.pdf.

Fullan, M. (2006). Uudne arusaam haridusmuutustest. Tartu: Atlex.

Haridus- ja Teadusministeerium (2013). Hariduslike erivajadustega ópilaste õppekorralduse kontseptsioon. Külastatud aadressil http://erut3m.havike.eenet.ee/hev/ wp-content/uploads/2014/02/HEV-\%C3\%B5oilaste-\%C3\%B5ppekorraldusekontseptsioon.pdf.

Haridus- ja Teadusministeerium (2015). Haridus- ja Teadusministeeriumi aasta-analüüs. Külastatud aadressil http://dspace.ut.ee/bitstream/handle/10062/47973/Aastaanalyys2015.pdf? sequence=8\&isAllowed $=$ yanalüüs.

Haridus- ja Teadusministeerium (2016). Hariduslike erivajadustega õpilane. Külastatud aadressil https://www.hm.ee/et/tegevused/alus-pohi-ja-keskharidus/hariduslike-erivajadustega-opilane. 
Hattie, J. A. C. (2012). Visible learning for teachers: Maximizing impact on achievement. Oxford: Routledge.

HKS 2014 = Maanso, V., Erelt, T., Kadakas, M., Kala-Arvisto, U., Kraav, I., Puksand, H., Tamm, E., \& Unt, I. (koost.) (2014). Hariduse ja kasvatuse sõnaraamat. Tallinn: Eesti Keele Sihtasutus.

Hornby, G. (2014). Special education today in New Zealand. In A. F. Rotatori, J. P. Bakken, S. Burkhardt, F. E. Obiakor, \& U. Sharma (Eds.), Advances in Special Education: Vol. 28. Special education international perspectives: Practices across the globe (pp. 643-660). Bingley: Emerald Group Publishing. doi: http://dx.doi.org/10.1108/s0270-401320140000028029

Häidkind, P. (2013). Koolieelne eripedagoogika ja/või alusharidus? Eripedagoogika: 45 aastat eripedagoogikat Eestis, 42, 13-14.

Häidkind, P., Palts, K., Pillmann, J., Ennok, K., Villems, K., \& Peterson, T. (2013). Lapse arengu hindamise ja toetamise juhendmaterjal koolieelsetele lasteasutustele. Külastatud aadressil https://www.hm.ee/sites/default/files/juhendmaterjal_alusharidus.pdf.

Jones, C. (2004). Supporting inclusion in the early years. Maidenhead, New York: Open University Press.

Kall, K. (2014). Õpetajate enesetäiendamine. Ü. Übius, K. Kall, K. Loogma, \& M. Ümarik (koost.), Rahvusvaheline vaade õpetamisele ja óppimisele. OECD rahvusvahelise õpetamise ja õppimise uuringu TALIS 2013 tulemused (lk 64-90). Tallinn: Innove. Külastatud aadressil http://uuringud.ekk.edu.ee/fileadmin/user_upload/documents/TALIS/TALIS2013_Eesti_raport.pdf.

Karlep, K. (2015). Kaasamisega kaasnevad probleemid. Eripedagoogika: HEV õpilaste kaasamine, 46, 40-74.

Kivirand, T. (2012). Kaasav haridus ja hariduslike erivajadustega õpilaste õppekorraldus. K. Hanga \& H. Voog (toim.), Heade praktikate kogumik: käsiraamat sotsiaalja haridustöötajatele, kuidas kaasata puudega inimesi (lk 55-57). Tallinn: Eesti Puuetega Inimeste Koda. Külastatud aadressil http://www.digar.ee/arhiiv/et/raamatud/16300.

Kollom, K., Kruusimägi, T., Laanela, M., Meinart, K., Niilo, A., Pedaste, M. ... Ülavere, P. (koost.) (2013). Kutsestandard. Õpetaja, tase 6. Külastatud aadressil http://kutsekoda.ee/et/kutseregister/kutsestandardid/10494424/pdf/opetaja-tase-6.1.et.pdf.

Koolieelse lasteasutuse pedagoogide kvalifikatsiooninõuded (2013). Riigi Teataja I, 06.09.2013, 36. Külastatud aadressil https://www.riigiteataja.ee/akt/103092013036.

Koolieelse lasteasutuse riiklik õppekava (2008). Riigi Teataja I, 23, 152. Külastatud aadressil https://www.riigiteataja.ee/akt/12970917.

Koolieelse lasteasutuse seadus (1999). Riigi Teataja I, 27, 387. Külastatud aadressil https://www.riigiteataja.ee/akt/114032011006.

Kraska, J., \& Boyle, C. (2014). Attitudes of preschool and primary school pre-service teachers toward inclusive education. Asia-Pacific Journal of Teacher Education, 42(3), 228-246. doi: http://dx.doi.org/10.1080/1359866X.2014.926307

Kruusamäe, R. (2015). Kaasav haridus, ópetajate vajadused ning ootused tugispetsialistidele hariduslike erivajadustega ópilaste ópetamisel Lääne-Virumaa koolides (magistritöö). Tartu Ülikool, Tartu. Külastatud aadressil http://dspace.ut.ee/handle/10062/48264. 
Kõrgesaar, J. (2002). Sissejuhatus hariduslike erivajaduste käsitlusse. Tartu: Tartu Ülikooli Kirjastus.

Lastekaitse Liit (2014). Laste ja noorte osalus ja kaasamine koolis. Kokkuvõte uuringust. Külastatud aadressil http://www.eetika.ee/sites/default/files/www_ut/laste_ ja_noorte_osalus_ja_kaasamine_koolis_0.pdf.

Lee, F. L. M., Yeung, A. S., Tracey, D., \& Barker, K. (2015). Inclusion of children with special needs in early childhood education: What teacher characteristics matter. Topics in Early Childhood Special Education, 35, 79-88. doi: http://dx.doi.org/10.1177/0271121414566014

Li, Y. L. (2004). A school-based project in five kindergartens: The case of teacher development and school development. International Journal of Early Years Education, 12(2), 143-155. doi: http://dx.doi.org/10.1080/0966976042000225534

Loreman, T., Forlin, C., Chambers, D., Sharma, U., \& Deppeler, J. (2014). Conceptualising and measuring inclusive education. In C. Forlin \& T. Loreman (Eds.), International Perspectives on Inclusive Education: Vol. 3. Measuring inclusive education (pp. 3-17). Bingley: Emerald Group Publishing. doi: http://dx.doi.org/10.1108/s1479-363620140000003015

Loreman, T., Forlin, C., \& Sharma, U. (2014). Measuring indicators of inclusive education: A systematic review of the literature. In C. Forlin \& T. Loreman (Eds.), International Perspectives on Inclusive Education: Vol. 3. Measuring inclusive education (pp. 165-187). Bingley: Emerald Group Publishing. doi: http://dx.doi.org/10.1108/s1479-363620140000003024

Mägi, E., \& Haljaste, A. (2001). Tavakoolide õpetajate suhtumine kõigi laste koosõpetamisse ja nende oskused erivajadustega laste õpetamisel tavaklassis. L. Talts (koost.), Algkooliõpilase arenguvõimalusi Eesti erinevates piirkondades. Algõpetuse aktuaalseid probleeme, 10 (lk 31-37). Tallinn: Tallinna Pedagoogikaülikool.

Nes, K. (2003). Why does education for all have to be inclusive education? In J. Allan (Ed.), Inclusion, participation and democracy: What is the purpose? (pp. 67-82). Dordrecht: Kluwer Academic Publishers.

doi: http://dx.doi.org/10.1007/0-306-48078-6_5

Oras, K. (2003). Võimalusi algajate õpetajate ning meisterõpetajate kutseoskuste erinevuse uurimiseks. E. Krull \& K. Oras (toim.), Õpetajate professionaalne areng ja õppepraktika (lk 158-173). Tartu: Tartu Ülikooli Kirjastus.

Pecek, M., Cuk, I., \& Lesar, I. (2008). Teachers' perceptions of the inclusion of marginalized groups. Educational Studies, 34(3), 225-239. doi: http://dx.doi.org/10.1080/03055690701811347

Pedaste, M., Meinart, K., Veesaar, E., Plado, K., Rannaääre, U., Laanela, M. ... Kruusimägi, T. (koost.) (2013). Kutsestandard. Oppetaja, tase 7. Külastatud aadressil http://kutsekoda.ee/et/kutseregister/kutsestandardid/10494558/pdf/opetaja-tase7.5.et.pdf.

Poom-Valickis, K., \& Loogma, K. (2009). Õpetajate enesetäiendamine. K. Loogma, V-R. Ruus, L. Talts, \& K. Poom-Valickis (koost.), Õpetaja professionaalsus ning tõhusama ópetamis- ja õppimiskeskkonna loomine. OECD rahvusvahelise ópetamise ja óppimise uuringu TALIS tulemused. Tallinn: Tallinna Ülikooli haridusuuringute keskus. Külastatud aadressil http://uuringud.ekk.edu.ee/fileadmin/ user_upload/documents/TALIS/TALIS_Eesti_2008_aruanne.pdf. 
Postak, J. (2015). Lasteaia tava- ja sobitusrühmade ópetajate kogemused autismiga lapse õpetamise kohta (bakalaureusetöö). Tartu Ülikool, Tartu. Külastatud aadressil http://dspace.ut.ee/handle/10062/48137.

Põhikooli- ja gümnaasiumiseadus (2010). Riigi Teataja I 2010, 41, 240. Külastatud aadressil https://www.riigiteataja.ee/akt/13332410.

Põhikooli riiklik õppekava (2011). Riigi Teataja I, 14.01.2011, 1. Külastatud aadressil https://www.riigiteataja.ee/akt/114012011001.

Robo, M. (2014). Social inclusion and inclusive education. Academicus - International Scientific Journal, 10, 191-201.

Rodriguez, I. R., Saldana, D., \& Moreno, F. J. (2012). Support, inclusion, and special education teachers' attitudes toward the education of students with autism spectrum disorders. Autism Research and Treatment, 2012, 1-8. doi: http://dx.doi.org/10.1155/2012/259468

Rogers, B. (2008). Taasleitud käitumine. Tartu: Tartu Ülikooli Kirjastus.

Schwab, S. (2015). Social dimensions of inclusion in education of 4 th and 7 th grade pupils in inclusive and regular classes: Outcomes from Austria. Research in Developmental Disabilities, 43-44, 72-79.

doi: http://dx.doi.org/10.1016/j.ridd.2015.06.005

Shapiro, A. (2000). Everybody belongs: Changing negative attitudes towards classmates with disabilities. London, New York: Routledge.

Skogen, K., \& Holmberg, J. B. (2004). Kohandatud ópe ja kaasav kool. Tartu: Haridusja Teadusministeerium.

Soiber, K. C., \& Gettinger, M. (2011). Functional assessment and positive support strategies for promoting resilience: Effects on teachers and high-risk children. Psychology in the Schools, 48(7), 686-706. doi: http://dx.doi.org/10.1002/pits.20587

Specht, J., McGhie-Richmond, D., Loreman, T., Mirenda, P., Bennett, S., Gallagher, T., ... Cloutier, S. (2016). Teaching in inclusive classrooms: Efficacy and beliefs of Canadian preservice teachers. International Journal of Inclusive Education, 20(1), 1-15. doi: http://dx.doi.org/10.1080/13603116.2015.1059501

Spratt, J., \& Florian, L. (2014). Developing and using a framework for gauging the use of inclusive pedagogy by new and experienced teachers. In C. Forlin \& T. Loreman (Eds.), International Perspectives on Inclusive Education: Vol. 3. Measuring inclusive education (pp. 263-278). Bingley: Emerald Group Publishing.

doi: http://dx.doi.org/10.1108/s1479-363620140000003029

Säälik, Ü., Mikk, J., Krips, H., \& Kalk, K. (2013). Õpilaste poolt õpetaja käitumisviisidele antavate hinnangute seostest õpilaste õpihuvi ning õpieduga. E. Krull, Ä. Leijen, M. Lepik, J. Mikk, L. Talts, \& T. Õun (toim.), Oppetajate professionaalne areng ja selle toetamine (lk 83-102). Eesti Ülikoolide Kirjastus.

Tropp, K., \& Saat, H. (2008). Sotsiaalsete oskuste areng. E. Kikas (toim.), Õppimine ja ópetamine koolieelses eas (lk 53-78). Tartu: Tartu Ülikooli Kirjastus.

Vujačić, M., \& Đević, R. (2013). Inclusive education: Conceptual definition, principles and characteristics. Casopis za Društvene Nauke, 37(2), 753-768.

Übius, Ü., Kall, K., Loogma, K., \& Ümarik, M. (2014). Rahvusvaheline vaade õpetamisele ja óppimisele. OECD rahvusvahelise ópetamise ja óppimise uuringu TALIS 2013 tulemused. Tallinn: Innove. Külastatud aadressil http://uuringud.ekk.edu.ee/ fileadmin/user_upload/documents/TALIS/TALIS2013_Eesti_raport.pdf. 


\title{
The notion of inclusive education and challenges for the teacher in kindergartens and the first stage of school
}

\author{
Pille Häidkind $^{\mathrm{a}}$, Kaja Oras ${ }^{\mathrm{b}}$ \\ ${ }^{a}$ University of Tartu, Institute of Education \\ ${ }^{b}$ Tallinn University, Institute of International Social Studies
}

\begin{abstract}
Summary
The objective of inclusive education is to improve the efficiency of the education system to reach all learners. What one deems to be inclusive education more precisely depends on what groups of learners can remain aside from education. In developed democratic countries most of all it is dealt with including learners with special educational needs (SEN) in ordinary schools at one's place of residence. Also the homepage of the Estonian Ministry of Education and Research (2016) formulates the essence of inclusive education as follows: "In the organisation of the studies of students with SEN, the principle of inclusive education is taken as a basis, according to which students with SEN study in the ordinary school at their place of residence as a rule." According to official statistics 13\% of learners in Estonian kindergartens and $17 \%$ in schools of general education have special educational needs.

This article focuses on the challenges that teachers encounter when dealing with inclusive education. Since the 1990s the learning differences within a group or class have increased, therefore, a modern teacher has to be highly flexible concerning her/his approaches. In professional standards (Kollom et al., 2013; Pedaste et al., 2013) it is clearly stated that dealing with children with SEN within a teaching group is an area of responsibility of the teacher. Research by students has shown, however, that Estonian teachers (19-95\% of interviewees) rather estimate their special pedagogical knowledge to be insufficient and respective in-service training is still one of the priorities in teacher training. Researchers have found that kindergarten teachers maintain a neutral attitude towards the inclusion of learners with special needs (Bendová et al., 2014), while primary school's teachers both neutral and negative ones (De Boera et al., 2011). Based on an overview by Hattie
\end{abstract}

Institute of Education, University of Tartu, Salme 1a, Tartu 50103, Estonia; pille.haidkind@ut.ee 
(2012) charting efficient study skills, an individual approach is worthy of application for the teacher.

The practice that learners with special needs are isolated somewhere and only specialists can deal with them has been in effect for decades. Within the context of inclusive education, the emphasis has shifted: the teacher has to be supported, advised and guided by support specialists. At that it is important, however, that special pedagogues, speech therapists, social pedagogues and psychologists enable the teacher and parent to control the process and take responsibility. Pecek, Cuk and Lesar (2008), for example, have found that class teachers accept only to a minor extent the fact that the inclusion of students with SEN is their responsibility.

To sum up it can be said that the ideas of inclusive education have been spreading in Estonia for 15-20 years as yet; there are laws, regulations, and a concept of the organisation of studies governing the area. However, major changes in education, take place slowly (Fullan, 2006) and analyses in the field of education carried out in 2015 (statistics and questionnaires) still refer to difficulties in the involvement of learners with SEN (inclusion has not become a natural part of pre-school or basic education). The objective of this research is to find out how inclusive education in kindergartens and schools (first stage of study) is defined and what are the challenges and solutions for a teacher in connection with the inclusion of learners in the ordinary educational system.

The research took place within the project "Child in a safe educational system: involvement and intervention for the interests of all children (2014-2016)" of NGO Hea Algus, and was funded with monies from the European Economic Area Grants programme "Children and Youth at Risk". Teams of 21 schools and 19 kindergartens (teacher, support specialist, members of management) from all over Estonia took part in the research. In the spring of 2015 team members filled in individual questionnaires and examinations of study and leisure activities $(60 \mathrm{~min})$ they performed. The teams were given five days training within the project. In the autumn the institutions were asked to cooperatively define what inclusive education is and to prepare a written plan for the promotion of inclusive education for one's institution concerning the academic year of 2015/2016. Research issues and answers thereto as a resulting from this data analysis are as follows:

1. What is the concept of inclusive education connected to? It became evident from individual interviews that inclusive education is rather defined more widely. If a child with special needs was highlighted, then an individual approach was promptly emphasised as well. Surprisingly, it emerged that inclusive education is rather the inclusion of learners in the 
study process, inclusion of support specialists and parents. When plans for the promotion of inclusive education were prepared after combined team training sessions at institutional level, inclusive education first and foremost was related to learners with SEN.

2. What options are outlined to promote inclusive education? It became evident from plans for inclusive education that activities can be aimed at children, teachers, parents, and the (additional) use of support structures, changing the environment or cooperation between different parties. In the work organisation of an institution possibilities are sought so that learners with SEN would be and learn with others as much as possible.

3. How are attitudes concerning inclusive education different in kindergarten and school? In kindergartens, the only support specialist was the speech therapist; in schools additionally a special pedagogue, social pedagogue and school psychologist were at work. School is mandatory and the processes taking place there (incl. inclusion) are more specifically regulated, having a stricter nature than in kindergarten. At the same time in the kindergartens in the groups at least two adults are at work and this results in better opportunities for teamwork.

4. What possibilities of adapting the organisation of studies and the environment do teachers know, and what problems they have experienced in connection with the inclusion of children with SEN? It became evident from the teachers' responses that there are problems dividing their attention between those with special needs, who have study and behavioural problems, and with the remainder of the class. Regarding the possibilities of adapting the physical and social environments, variations of the room, furniture, tools, and relationships between people, the size of the group, supporting personal were mentioned. More frequent training of teachers and the development of teamwork in the institutions were given as solutions to these problems.

5. How do learners in the same group feel during studies and leisure, how does the teacher react to an individual child? It became evident that bad or hard feelings during studies were expressed by the behaviour of ordinary children, rather than children differing from others. The teacher's reactions to a difficult child, especially in kindergarten, were more positive and supportive.

Results obtained during the research might have a practical output for teacher training. For the development of inclusive education, it is still required to teach in high schools who and what children with SEN are (attention has to be paid to the peculiarities, support of studies and behaviour). Similarly, it is also important to prepare teachers for the joint 
teaching of a learner with SEN and the remaining children (group processes, control). Inclusive education should not operate at the expense, or cause suffering to anyone, rather that the teacher should understand the implications surrounding the physical and social environment of the learners. As a result of the research it can be stated that the inclusion of children with special needs takes place in Estonian kindergartens to a somewhat greater extent than in schools.

Keywords: inclusive education, children with SEN, kindergarten teachers, primary school teachers 